\title{
REGULASI OSMOTIK DAN NILAI HEMATOKRIT IKAN NILA (Oreochromis sp.) PADA MEDIUM DENGAN SALINITAS DAN TEMPERATUR AIR BERBEDA
}

\author{
Untung Susilo, Wahyu Meilina, dan Sorta Basar Ida Simanjuntak \\ Fakultas Biologi Universitas Jenderal Soedirman, Purwokerto \\ Corresponding author (E-mail: susilo.utg@gmail.com)
}

\begin{abstract}
Osmotic regulation and blood hematocrite of nile, Oreochromis sp., have been evaluated as response to different salinity and water temperature. Three different salinities ( 0 ppt, 10 ppt and 20 ppt) in combination with two different water temperatures $\left(26^{\circ} \mathrm{C}\right.$ and $\left.30^{\circ} \mathrm{C}\right)$ have been applicated in this experiment. Fish with average body weight $28.3 \pm 2.62 \mathrm{~g}$ were used ini this experiment. The result showed that plasma osmolality of nile in freshwater have not different with in $10 \mathrm{ppt}(\mathrm{P}>0.05)$, but plasma osmolality increased at 20 ppt especially at 8,16 and 24 hours after aclimated on 20 ppt. Osmoregulatory capacity has significant heigher $(P<.05)$ on nile in freshwater than in water with salinity 10 ppt and 20 ppt. Body water content and blood hematocrite were not significant between different salinity and water temperature $(P>$ .05). Conclution, osmotic regulation of nile showed significant different between salinity treatment, but blood hematocrite only changed at 8, and 16 hours after nile aclimated on water salinity 20 ppt and body water content not changed at both diferent salinity and water temperature.
\end{abstract}

Key words: Body water content, Hematocrite, Oreochromis sp., Osmoregulation

\section{PENGANTAR}

Pada umumnya ikan yang hidup di air tawar meregulasi cairan osmotik internal untuk selalu dipertahankan lebih tinggi dari pada konsentrasi osmotik lingkungannya atau bersifat hiper-osmoregulator, sedangkan ikan laut, terutama ikan teleostei, umumnya bersifat hipo-osmoregulator yaitu meregulasi cairan internalnya lebih rendah dari pada lingkungannya (Schmidt-Nielsen, 1990; Randall et al., 2002). Untuk mengatasi problem osmotiknya, pada umumnya ikan air tawar sedikit minum, menghasilkan urine encer dan aktif mengabsorpsi garam dari lingkungannya melalui insang (Randall et al., 2002; Takei dan Hirose, 2001). Sebaliknya ikan laut mengatasi problem osmotiknya dengan cara minum air laut, mengekskresikan ion lewat insang dan urine, serta menghasilkan sedikit urine (Randall et al., 2002; Bayenbach dalam Takei dan Hirose, 2001).

Pada umumnya ikan air tawar dan air laut memiliki kemampuan terbatas untuk mentoleransi perubahan salinitas medium atau bersifat stenohaline, namun di antara ikan ada yang memiliki kemampuan besar untuk mentoleransi perubahan salinitas medium dengan rentang yang luas atau disebut bersifat eurihaline. Ikan nila adalah salah satu jenis ikan yang termasuk bersifat eurihaline, namun demikian bagaimana dan sampai seberapa jauh ikan nila mampu merespons terhadap perubahan faktor lingkungan masih perlu untuk dikaji.
Studi terdahulu untuk mengkaji perubahan regulasi osmotik terhadap perubahan salinitas medium telah banyak dilakukan, diantaranya pada ikan Fundulus heterooclitus (Gordon et al., 1982), salmon Atlantik, Salmo salar L., (Handeland et al., 1998), ikan mujair (Nolan et al., 1999), ikan nila merah (Hariyadi, 2003), ikan bandeng (Yuwono et al., 2005), ikan sidat (Susilo dan Sukmaningrum, 2007), namun belum banyak informasi yang berkaitan dengan regulasi osmotik dan nilai hematokrit darah ikan nila sebagai respons terhadap perbedaan salinitas dan temperatur air.

Tujuan penelitian ini adalah untuk mengetahui regulasi osmotik internal dan nilai hematokrit darah ikan nila, Oreochromis sp., sebagai respons terhadap perbedaan salinitas dan termperatur air medium hidupnya.

\section{BAHAN DAN CARA KERJA}

\section{Bahan dan Alat Penelitian}

Ikan nila (Oreochromis sp.) yang digunakan dalam penelitian ini diperoleh dari balai benih ikan Tambaksogra, Banyumas. Ukuran ikan rata-rata yang digunakan adalah $28,3 \pm 2,62$ g dengan umur berkisar antara $2-3$ bulan. Alat yang digunakan dalam penelitian ini meliputi akuarium kaca ukuran $30 \times 35 \times 50 \mathrm{~cm}$, timbangan teknikal dengan ketelitian $0,1 \mathrm{~g}$, osmometer vapour Wescor, mikrohematokrit elektronik, dan hematokrit reader. 


\section{Cara Kerja}

Metode penelitian yang digunakan adalah eksperimental menggunakan rancangan acak lengkap (RAL) dengan 6 perlakuan dan 5 ulangan. Perlakuan yang dicobakan adalah sebagai berikut: Ikan nila dipaparkan dalam medium dengan salinitas 0 ppt dan temperatur air $26 \pm 1^{\circ} \mathrm{C}$ (S0T26); Ikan nila dipaparkan dalam medium dengan salinitas 0 ppt dan temperatur air $30 \pm 1^{\circ} \mathrm{C}$ (S0T30); Ikan nila dipaparkan dalam medium dengan salinitas $10 \mathrm{ppt}$ dan temperatur air $26 \pm 1^{\circ} \mathrm{C}$ (S10T26); Ikan nila dipaparkan dalam medium dengan salinitas 10 ppt dan temperatur air $30 \pm 1^{\circ} \mathrm{C}(\mathrm{S} 10 \mathrm{~T} 30)$; Ikan nila dipaparkan dalam medium dengan salinitas 20 ppt dan temperatur air $26 \pm 1^{\circ} \mathrm{C}$ (S20T26); Ikan nila dipaparkan dalam medium dengan salinitas $20 \mathrm{ppt}$ dan temperatur air $30 \pm 1{ }^{\circ} \mathrm{C}$ (S20T30).

Parameter yang diukur dan dihitung pada penelitian ini meliputi nilai osmolalitas plasma darah, kapasitas osmoregulasi, kadar air tubuh dan nilai hematokrit. Pengambilan sampel darah untuk pengamatan osmolalitas plasma darah, kapasitas osmoregulasi dan dilakukan pada lama pemaparan 4, 8, 16, 24, 48 dan 168 jam, sedangkan pengambilan sampel untuk pengamatan kadar cairan tubuh dilakukan pada lama pemaparan 24 dan 48 jam.

Sampel darah ikan untuk keperluan pengambilan plasma darah, diperoleh dengan melakukan pemotongan pangkal ekor dan darah yang mengalir langsung ditampung dengan kapiler hematokrit berheparin. Sampel darah yang diperoleh disentrifugasi pada kecepatan $5500 \mathrm{rpm}$ selama tiga menit (Metode Partidge dan Jenkins, 2000).

Plasma darah yang diperoleh selanjutnya dicuplik sebanyak $10 \mu 1$ untuk diukur nilai osmolalitasnya menggunakan osmometer Wescor (Wescor Vapour Osmometer). Nilai osmolalitas plasma darah yang diperoleh akan dinyatakan dalam satuan $\mathrm{mOsm} / \mathrm{kg}$ pelarutnya. Untuk keperluan perhitungan kapasitas osmoregulasi maka diukur juga nilai osmolalitas medium dengan metode yang sama menggunakan osmometer Wescor. Kapasitas osmoregulasi dikalkulasi dari rasio antara nilai osmolalitas plasma darah dengan osmolalitas medium (Lignot et al., 2000).

Untuk keperluan penghitungan kadar air tubuh, maka pada pemaparan 24 jam dan 48 jam, diambil sampel ikan, lalu ditimbang berat basahnya dan selanjutnya dikeringkan dalam oven dengan suhu $70^{\circ} \mathrm{C}$ hingga beratnya konstan. Setelah kering ikan ditimbang berat tubuhnya. Kadar air tubuh ikan dinyatakan sebagai selisih antara berat tubuh basah dengan berat kering dibagi berat basah ikan kali seratus persen (Plaut, 1998).

Nilai hematokrit darah dihitung dengan cara manual yaitu sampel darah yang diperoleh dalam tabung mikrohematokrit berheparin disentrifugasi pada kecepatan $5.500 \mathrm{rpm}$ selama 3 menit dan setelah setrifugasi persentase korpuskula darah yang terpisah dari plasmanya diukur menggunakan "Hawksley reader" dalam satuan \% (Schalm, 1989). Nilai hematokrit akan mencerminkan persentase padatan darah terhadap volume darah.

Data penelitian yang meliputi nilai osmolaitas plasma darah, kapasitas osmoregulasi, kadar air tubuh dan nilai hematokrit dianalisis dengan uji F (Steel dan Torrie, 1981).

\section{HASIL}

Hasil pengukuran osmolalitas plasma darah ikan nila setelah pemaparan pada medium dengan salinitas dan temperatur air berbeda tersaji pada gambar 1. Osmolalitas plasma darah ikan yang dipaparkan selama 4 hingga 168 jam berkisar antara $211,3-360 \mathrm{mOsm} / \mathrm{kg}$ pada salinitas 0 dan 10 dengan temperatur 26 dan $30^{\circ} \mathrm{C}$. Osmolalitas plasma darah ikan nila yang dipaparkan pada salinitas 20 dengan temperatur 26 dan $30^{\circ} \mathrm{C}$ berkisar $363,2-539,7$ $\mathrm{mOsm} / \mathrm{kg}$ dengan lama pemaparan 4-24 jam, sedangkan pada pemaparan 48-168 jam berkisar 299,5-391 mOsm $/ \mathrm{kg}$ (gambar 1). Uji statistik juga menunjukkan adanya perbedaan yang signifikan di antara perlakuan yang diterapkan $(\mathrm{P}<$ $.05)$.

Kapasitas osmoregulasi ikan nila yang dipaparkan selama 4-168 jam pada medium salinitas 0 ppt dengam temperatur air $26^{\circ} \mathrm{C}$ dan $30^{\circ} \mathrm{C}$ berkisar 2,02-3, 00 , kapasitas osmoregulasi ikan nila yang dipaparkan pada medium salinitas $10 \mathrm{ppt}$ dengan temperatur air $26^{\circ} \mathrm{C}$ dan $30^{\circ} \mathrm{C}$ berkisar $0,86-1,18$, sedangkan kapasitas osmoregulasi ikan nila yang dipaparkan pada medium salinitas $20 \mathrm{ppt}$ dengan temperatur air $26^{\circ} \mathrm{C}$ dan $30^{\circ} \mathrm{C}$ berkisar 0,50 0,96 (gambar 2). Uji statistik juga menunjukkan adanya perbedaan yang signifikan di antara perlakuan yang diterapkan $(\mathrm{P}<.05)$.



Gambar 1. Osmolalitas plasma darah ikan nila pada berbagai perlakuan 


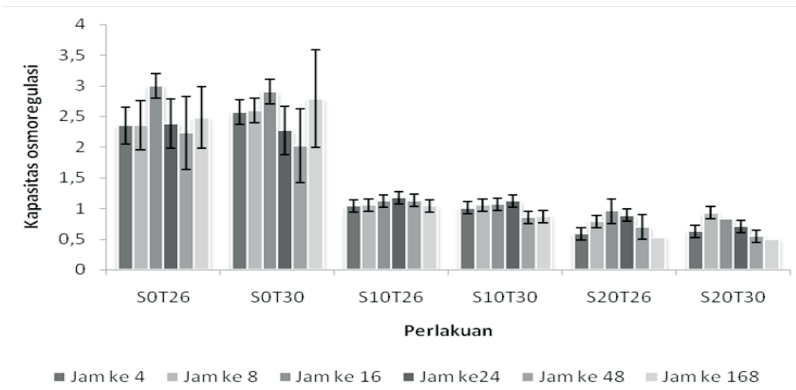

Gambar 2. Kapasitas osmoregulasi ikan nila pada berbagai perlakuan

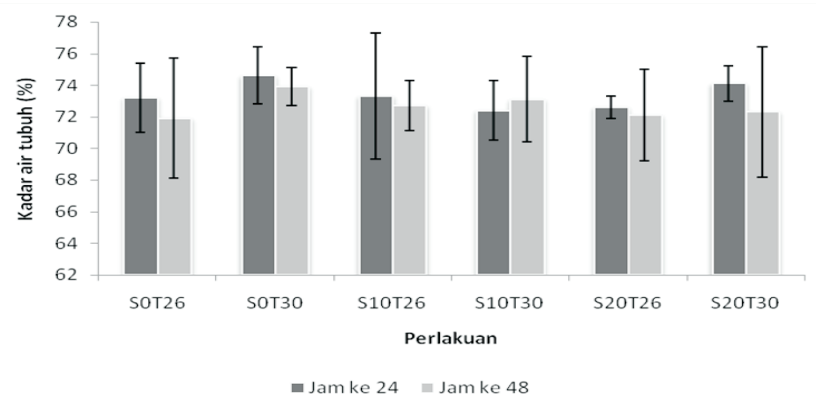

Gambar 3. Kadar air tubuh ikan nila pada pengukuran setelah 24 dan 48 permaparan

Kadar air tubuh ikan nila diukur pada 24 jam dan 48 jam setelah pemaparan di medium dengan salinitas dan temperatur air berbeda. Kadar air tubuh ikan nila yang dipaparkan di salinitas $0 \mathrm{ppt}$ baik untuk temperatur air $26^{\circ} \mathrm{C}$ maupun $30^{\circ} \mathrm{C}$ berkisar 71,9-74,6 \%, kadar air tubuh ikan nila yang dipaparkan di aslinitas 10 ppt baik untuk temperatur air $26^{\circ} \mathrm{C}$ maupun $30^{\circ} \mathrm{C}$ berkisar $72,4-73,1 \%$, dan kadar air tubuh ikan nila yang dipaparkan di salinitas 20 ppt baik untuk temperatur air $26^{\circ} \mathrm{C}$ maupun $30^{\circ} \mathrm{C}$ berkisar 72,1-74,1\% (gambar 3). Hasil uji statistik baik untuk pemaparan 24 jam maupun 48 jam menunjukkan tidak adanya perbedaan yang signifikan di antara perlakuan yang diterapkan $(\mathrm{P}>.05)$.

Hasil pengukuran nilai hematokrit ikan nila yang dilakukan setelah pemaparan 4 jam hingga 168 jam pada berbagai salinitas dan temperatur medium, tersaji pada gambar 4. Pada gambar 4 terlihat nilai hematokrit ikan nila yang dipaparkan selama 4 jam hingga 168 jam pada salinitas 0 ppt dan temperatur air $26^{\circ} \mathrm{C}$ dan $30^{\circ} \mathrm{C}$ berkisar $29,5-41,5 \%$, nilai hematokrit ikan nila yang dipaparkan selama 4 jam hingga 168 jam pada salinitas 10 ppt dan temperatur air $26^{\circ} \mathrm{C}$ dan $30^{\circ} \mathrm{C}$ berkisar $22,2-33,8 \%$, dan nilai hematokrit ikan nila yang dipaparkan selama 4 jam hingga 168 jam pada salinitas $20 \mathrm{ppt}$ dan temperatur air $26^{\circ} \mathrm{C}$ dan $30^{\circ} \mathrm{C}$ berkisar $33,0-50,8 \%$ Hasil uji statistik juga

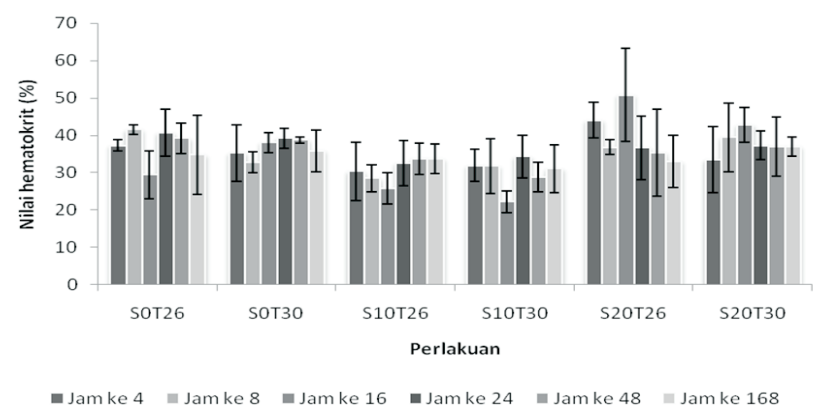

Gambar 4. Nilai hematokrit ikan nila pada berbagai perlakuan

menunjukkan terdapat perbedaan yang siginfikan di antara perlakuan yang diterapkan $(\mathrm{P}<.05)$ pada pemaparan 8 dan 16 jam, namun tidak terdapat perbedaan yang signifikan $(\mathrm{P}$ $>$.05) pada pemaparan 4, 24, 48, dan 168 jam.

\section{PEMBAHASAN}

Ikan nila yang dipaparkan pada temperatur $26^{\circ} \mathrm{C}$ dan $30^{\circ} \mathrm{C}$ di salinitas $10 \mathrm{ppt}$, konsentrasi internalnya tidak mengalami perubahan yang signifikan dibandingkan yang dipaparkan di air tawar (0 ppt). Kondisi ini berbeda ketika ikan ditempatkan pada salinitas yang lebih tinggi yaitu salinitas 20 ppt, osmolalitas plasma darah ikan nila mengalami peningkatan yang signifikan terutama pada lama pemapaan 8, 16 dan 24 jam, namun osmolalitas plasma darah kemudian mengalami penurunan ketika ikan dipaparkan selama 48 dan 168 jam baik pada temperatur $26^{\circ} \mathrm{C}$ maupun $30^{\circ} \mathrm{C}$. Fenomena peningkatan osmolaritas pada salinitas 20 ppt, juga dijumpai pada ikan salmon atlantik, Salmo salar, yang mengalami peningkatan konsentrasi ion klorid plasma setelah pemaparan selama 12 jam di lingkungan air laut (Handeland et al., 1998), namun hasil penelitian ini berbeda dengan yang dijumpai pada ikan Salario fluviatilis (ikan air tawar) yang osmolalitasnya tidak mengalami perubahan setelah aklimasi diperairan bersalinitas selama tiga bulan (Plaut, 1998) dan juvenil ikan turbot, Scophthalmus maximus, yang osmolalitas plasma darahnya dipengaruhi oleh perbedaan salinitas hanya pada temperatur aklimasi yang rendah (Imsland et al., 2003). Fenomena perubahan osmolalitas plasma darah pada aklimasi awal ikan nila di salinitas 20 ppt diduga berhubungan dengan kesiapan organ osmoregulasi ikan bila dipindah ke perairan bersalinitas. Guner et al. (2005) menyatakan bahwa pada ikan tilapia yang dipindah ke perairan bersalinitas akan melibatkan perubahan fungsional sel-sel klorid dan aktivitas $\mathrm{Na}^{+}-\mathrm{K}^{+}$-ATPase. Jadi bila ikan dipindah ke perairan bersalinitas maka sel-sel kloride tipe air laut dan $\mathrm{Na}^{+}-\mathrm{K}^{+}$-ATPase di insang harus diaktifkan 
untuk bekerja mengeluarkan kelebihan garam yang masuk tubuh secara pasif. Meningkatnya aktivitas sel klorid $\mathrm{Na}^{+}-\mathrm{K}^{+}$-ATPase di insang ditunjukkan oleh menurunnya osmolalitas plasma pada ikan yang dipaparkan selama 48 dan 168 jam.

Kapasitas osmoregulasi yang mencerminkan besarnya kerja osmotik yang dilakukan ikan dapat dinyatakan oleh perbedaan osmolalitas plasma darah dengan osmolalitas medium. Pada ikan nila yang dipaparkan di medium air tawar memiliki kapasitas osmoregulasi yang paling tinggi di antara perlakuan yang lain, hal ini menunjukkan bahwa ikan di medium air tawar memiliki kapasitas osmoregulasi yang besar untuk mengatur perbedaan osmotik internalnya dengan medium hidupnya. Pada ikan nila yang ditempatkan di medium dengan salinitas 10 ppt kapasitas osmoregulasinya mendekati atau berkisar satu baik ikan yang ditempatkan pada temperatur air $26^{\circ} \mathrm{C}$ maupun $30^{\circ} \mathrm{C}$, yang bermakna bahwa osmolalitas plasma darahnya hampir sama dengan osmolalitas medium hidupnya. Pada kondisi demikian ikan tidak memerlukan banyak usaha untuk melakukan regulasi osmotik internalnya, karena ikan berada pada kondisi isoosmotik. Nilai kapasitas osmoregulasi sedikit mengalami penurunan pada ikan yang ditempatkan di medium dengan salinitas $20 \mathrm{ppt}$, karena osmolalitas plasmanya lebih rendah dari pada osmolalitas mediumnya. Perbedaan kapasitas osmoregulasi pada ikan nila dalam penelitian ini juga lebih ditentukan oleh perbedaan salinitas medium, tidak ditentukan oleh perbedaan temperatur air. Pengaturan osmotik yang dilakukan pada salinitas $20 \mathrm{ppt}$ praktis sedikit berbeda dibandingkan dengan ikan yang ditempatkan di salinitas $10 \mathrm{ppt}$. Namun, pengaturan osmotik di lingkungan salinitas $20 \mathrm{ppt}$, berlawanan dengan ikan yang ditempatkan di salinitas 0 ppt (air tawar). Kondisi isoosmotik ikan nila yang ditempatkan pada salinitas 10-20 ppt pada penelitian ini juga dijumpai pada ikan nila pada penelitian Pirzan dan Tahe (1995) dan ikan nila merah strain Florida (Watanabe et al., 1992). Rendahnya nilai kapasitas osmoregulasi pada ikan nila yang ditempatkan pada salinitas 20 ppt, menunjukkan bahwa ikan nila berada pada medium hiperosmotik terhadap cairan internalnya, dan kondisi ini berbeda dengan ikan nila yang ditempatkan pada medium air tawar (salinitas $0 \mathrm{ppt}$ ).

Tidak terdapat perbedaan yang signifikan kadar air tubuh ikan nila yang dipaparkan selama 24 dan 48 jam pada berbagai salinitas dan temperatur medium, yang menunjukkan bahwa kadar air tubuh cenderung konstan, walaupun ikan ditempatkan pada medium dengan salinitas dan temperatur air berbeda. Fenomena ini tidak berbeda dengan yang dijumpai pada ikan sidat tropik (Susilo dan
Sukmaningrum, 2007), ikan air tawar Salario fluviatilis (Plaut, 1998), namun hasil penelitian ini berbeda dengan yang diamati pada ikan Salmon Atlantik, Salmo salar, yang mengalami peningkatan kadar air otot setelah dipindah ke air laut selama 24 jam pada temperatur air $8^{\circ} \mathrm{C}$ dibandingkan dengan yang diklimasi pada temperatur $4^{\circ} \mathrm{C}$ (Handeland et al., 1998) dan ikan laut Salario pavo yang kadar air tubuhnya meningkat dengan menurunnya salinitas medium (Plaut, 1998).

Nilai hematokrit darah yang mencerminkan persentase volume keping darah terhadap volume darah, menunjukkan perbedaan di antara ikan yang dipaparkan pada salinitas 0 , 10 dan 20 ppt hanya pada lama pemaparan 8 dan 16 jam, namun nilai hematokrit tidak menunjukkan perbedaan yang signifikan pada ikan yang dipaparkan selama 4, 24, 48 dan 168 jam baik pada temperatur air $26^{\circ} \mathrm{C}$ maupun $30^{\circ} \mathrm{C}$. Hal ini menunjukkan bahwa walaupun ikan nila ditempatkan pada medium dengan salinitas berbeda dan melakukan pengaturan konsentrasi osmotik internal, tidak menyebabkan perubahan yang siginifikan nilai hematokrit darah kecuali pada pemaparan 8 dan 16 jam. Perbedaan ini diduga merupakan respons ikan dalam rangka menata ulang mekanisme osmoregulasi berkaitan dengan perubahan salinitas. Pada ikan yang dipindah dari air tawar ke air laut, maka ikan akan berusaha untuk mengatur secara terbalik aliran air dan ion agar dapat lolos hidup di lingkungan yang baru. Pada umumnya ikan yang dipindah ke perairan laut akan kehilangan banyak cairan pada awal aklimasi, dan ini diduga berkorelasi dengan meningkatnya nilai hematokrit darah pada ikan yang dipindah ke air laut pada awal aklimasi yaitu pada pemaparan 8 dan 16 jam dan faktor penyebab perbedaan juga bukan perbedaan temperatur air, namun lebih disebabkan oleh perbedaan salinitas medium. Perubahan nilai hematokrit pada pemaparan 8 dan 16 jam diduga disebabkan oleh perubahan salinitas medium yang menyebabkan stres pada ikan, sebab menurut Mazur dan Iwana (1993) kondisi stres pada hewan dapat menyebabkan peningkatan nilai hematokrit darah. Bila kondisi sudah normal kembali maka nilai hematokrit dapat kembali normal, ini yang dijumpai pada ikan yang diaklimasi selama 24, 48 dan 168 jam pada salinitas yang berbeda. Hasil penelitian ini juga tidak berbeda dengan yang dijumpai pada silver catfish Rhamdia quelen, perbedaan temperatur aklimasi tidak menyebabkan perbedaan nilai hematokrit darah (Lermen et al., 2004).

Kesimpulan yang dapat ditarik dari penelitian ini adalah regulasi osmotik ikan nila yang tercermin dalam osmolalitas plasma dan kapasitas osmoregulasi mengalami perubahan yang signifikan berkaitan dengan perubahan salinitas 
medium, dan nilai hematokrit mengalami perubahan hanya pada aklimasi 8 dan 16 jam dan tidak terdapat perbedaan kadar air tubuh pada aklimasi 24 dan 48 jam.

\section{KEPUSTAKAAN}

Gordon, M.S., George, A.B., Grinnell, A.D., Jorgensen, C.B., dan F.N. White. 1982. Animal Physiology Principle and Adapatations. $4^{\text {th }}$. MacMillan Publishing Co. Inc, New York.

Guner, Y., Ozden, O., Cagirgan, H., Altunok, M., dan Kizak, V. 2005. Effect of salinity on the osmoragulatory functions of the gills in nile tilapia (Orechromis niloticus). Turk $J$ Vet Anim Sci 29: 1259-1266.

Handeland, S.O., Berge, A., Bjornsson, B.Th., dan Stefansson, S.O. 1998. Effects of temperature and salinity on osmoregulation and growth of Atlantic salmon (Salmo salar L.) smolts in seawater. Aquaculture 168: 289-302.

Hariyadi, B. 2003. Darah dan tekanan osmotik ikan nila, Oreochromis sp., yang didedahkan dalam medium dengan salinitas berbeda. Sains Akuatik 6: 27-33.

Imsland, A.K., Gunnarsson, S., Foss, A., dan Stefansson, S.O. 2003. Gill $\mathrm{Na}^{+}, \mathrm{K}^{+}$ATPase activity, plasma chloride and osmolality in juvenile turbot (Scophthalmus maximus) reared at different temperatures and salinities. Aquacultur 218: 671-683.

Lermen, C.L., Lappe, R., Crestani, M., Vieira, V.P., Gioda, C.R., Schetinger, M.R.C., Baldisserotto, B., Moraes, G., dan Morsch, V.M. 2004. Effect of different temperature regimes on metabolic and blood parameters of silver catfish Rhamdia quelen. Aquaculture 239: 497-507.

Lignot, J.H., Pierot, C.S., dan Charmantier, G. 2000. Osmoregulatory capacity as a tool in monitoring the physiological condition and the effect of stress in crustaceans. Aquaculture 191: 209-245.

Mazur, C.F., dan Iwana, G.K. 1993. Effect of handling and stocking density on hematokrit, plasma cortisol, and survival in wild and hatchery-reared chinok salmon, Onchirhynchus tshawytscha. Aquaculture 112: 291-299.
Nolan, D.T., Op't Veld, R.L.J.M., Balm, P.H.M., dan Wendelaar Bonga, S.E.. 1999. Ambient salinity modulates the response of the tilapia, Oreochromis mosambicus (Peters) to net confinement. Aquaculture 177: 297-309.

Partridge, G.J. dan Jenkins, G.I. 2000. The effect of salinity on growth and survival of juvenile black bream (Acanthopagrus butcheri). Aquaculture 210: 219-230.

Pirzan, A.M., dan Tahe, S. 1995. Pengaruh salinitas terhadap kelangsungan hidup dan pertumbuhan ikan nila, Oreochromis niloticus. Jurnal Penelitian Perikanan Darat 1: 67-71.

Plaut. 1998. Comparation of salinity tolerance and osmoregulation in two closely related species of blennies from different habitats. Fish Physiology and Biochemestry 19: 81-88.

Randall, D., Burggren, W., dan French, K. 2002. Eckert, Animal Physiology Mechanisms and Adaptations. WH Freeeman and Company, New York. 588-621.

Schalm, O.W. 1989. Veterinary Hematology, $2^{\text {nd }}$ edition. Lea and Fabiger, Philadelphia.

Schmidt., dan Nielsen, K. 1990. Animal Physiology, Adaptation and Enviroment, $4^{\text {th }}$ ed. Cambridge University Press, Australia. 313-322.

Steel, R.G.D., dan Torrie, J.H. 1981. Principles and Procedures of Statistic, Abiometrical Approach. McGraw-Hill, London.

Susilo, U., dan Sukmaningrum, S. 2007. Osmoregulasi ikan sidat, Anguilla bicolor McClelland, pada media dengan salinitas berbeda. Sains Akuatik 10(2): 111-119.

Takei, Y., dan Hirose, S. 2001. The natriuretic peptide system in eel; a key endocrine system for euryhalinity. Am. J. Physiol. Regulatory Integrative Comp. Physiol 282: R940-R951.

Watanabe, W.O., Smith, S.J., Wicklund, R.I., dan Olla, B.L. 1992. Hatchery production of Florida red tilapia seed in brackish water tanks under natural mouthbrooding and clutch removal methods. Aquaculture 102: 77-88.

Yuwono E., Sukardi P., Sulistyo I., Hariyadi B., dan Khaerunisah. 2005. Osmoregulasi ikan bandeng (Chanos chanos) yang diaklimatisasi dalam salinitas medium. Kumpulan Abstrak Seminar Nasional Biologi dan Akuakultur Berkelanjutan. 10 September 2005. Fakultas Biologi Universitas Soedirman, Purwokerto. 